Georgetown University Law Center

Scholarship @ GEORGETOWN LAW

2019

\title{
Analyzing Vertical Mergers to Avoid False Negatives: Three Recent Case Studies
}

Steven C. Salop

Georgetown University Law Center, salop@law.georgetown.edu

This paper can be downloaded free of charge from:

https://scholarship.law.georgetown.edu/facpub/2151

https://ssrn.com/abstract $=3360420$

This open-access article is brought to you by the Georgetown Law Library. Posted with permission of the author. Follow this and additional works at: https://scholarship.law.georgetown.edu/facpub

Part of the Antitrust and Trade Regulation Commons, and the Law and Economics Commons 
Draft: April 5, 2019

\section{Analyzing Vertical Mergers to Avoid False Negatives: \\ Three Recent Case Studies \\ Steven C. Salop*}

\section{Introduction}

Vertical mergers have come into the news. Much has been written about the AT\&T/Time Warner vertical merger case as the first fully litigated governmental vertical merger case in four decades. ${ }^{1}$ There is now serious discussion regarding possible revision of the Vertical Merger Guidelines ("VMGs"). ${ }^{2}$ One pushback is the view that no specific false negatives have been identified in recent years, so that there is no problem to fix. In fact, a number of recent empirical articles using the most advanced empirical methodologies do often find evidence of anticompetitive effects. ${ }^{3}$ However, this econometric evaluation is a difficult exercise because the

\footnotetext{
* Professor of Economics and Law, Georgetown University Law Center and Senior Consultant, Charles River Associates (CRA). I would like to thank Jonathan Baker, Joseph Farrell, David Gelfand, Jonathan Jacobson, Thomas Krattenmaker and Carl Shapiro for helpful comments on an earlier draft and Tomasz Mielniczuk for research assistance. The analysis and opinions expressed here are my own and do not necessary reflect the views of these colleagues, CRA, or any of the firms (or counsel) discussed here. I consulted with Masonite in the 2001 Masonite/Premdor merger, but not the three vertical merger matters discussed here.
}

${ }^{1}$ U.S. v AT\&T, 310 F.Supp.3d 161 (2018). I have written elsewhere about this merger. Steven C. Salop, The AT\&T/Time Warner Merger: How Judge Leon Garbled Professor Nash, 6 J. ANTITRUST ENFORCEMENT 459 (2018). For different views, see Janusz A. Ordover, J. Gregory Sidlak \& Robert D. Willing, Is Professor Salop Right That Judge Leon Bungled United States v. AT\&T?, 3 CRITERION J. INNOVATION 249 (2018), https://www.criterioneconomics.com/docs/ordover-sidak-willig-professorsalop-and-us-v-att.pdf; Joshua D. Wright \& Jan M. Rybnicek, United States $v$ AT\&T: A Triumph of Economic Analysis, 6 J. ANTITRUST ENFORCEMENT 469 (2018).

${ }^{2}$ I provided my analysis and preferred general approach to vertical merger enforcement at the FTC Hearing on vertical mergers and in several recent articles. Steven C. Salop, Revising the Vertical Merger Guidelines (Fed. Trade Comm'n Hearing \#5 on Competition and Consumer Protection in the 21st Century 5, Nov. 1, 2018), http://www.ftc.gov/sites/default/files/documents/reports/consumer-fraudunited-states-second-federal-tra de-commission-survey-staff-report-federal-trade/fraud.pdf; Steven C. Salop, Invigorating Vertical Merger Enforcement 127 YALE L.J 1962 (2018); Steven C. Salop \& Daniel P. Culley, Revising the U.S. Vertical Merger Guidelines: Policy Issues and an Interim Guide for Practitioners, 4 J. ANTITRUST ENFORCEMENT 1 (2016).

${ }^{3}$ Some examples from the last decade include Fernando Luco \& Guillermo Marshall, Vertical Integration with Multiproduct Firms: When Eliminating Double Marginalization May Hurt Consumers (Jan. 15, 
necessary data often is not available and it very difficult to identify the effects of the merger, as opposed to other market changes. In addition, it generally will be impossible to infer from the data whether any efficiency benefits achieved were merger-specific.

Another possibility is to evaluate the analysis carried out by the reviewing agency during the HSR process to determine whether that analysis was complete. This would include examination of the competitive harm theories identified, the analysis carried out, and determination of whether the inferences drawn from the facts and theories were reliable. This examination also might determine if it is a close case so that a somewhat different evidentiary standard would have led to the opposite enforcement decision.

This type of evaluation by outsiders is very difficult. As FTC Bureau of Competition Director, Bruce Hoffman, has observed, "in addition to being highly idiosyncratic for each transaction, [the documentary and witness evidence] also tend to be non-public, and thus difficult for outside observers to assess when attempting to predict or critique our enforcement decisions. ${ }^{4}$ This is unfortunate. Greater transparency can provide important guidance for firms and their antitrust advisors. In addition, continued evaluation can lead to improvements in analytics and agency decisions over time.

This article carries out some preliminary analysis and evaluation of two recent vertical merger matters investigated and cleared (with limited remedies) in early 2019 by the Federal Trade Commission ("FTC" or "Commission") The Commission cleared the Staples/Essendant

2018) (working paper), https://ssrn.com/abstract=3110038; Laurence C. Baker et al., Does Multispecialty Practice Enhance Physician Market Power? (Nat'1 Bureau of Econ. Research, Working Paper No. 23871, 2017), http://www.nber.org/papers/w23871; Leemore Dafny et al., The Price Effects of Cross-Market Hospital Mergers (Nat'l Bureau of Econ. Research, Working Paper No. 22106, 2018) (addressing mergers involving demand complements); Jean-François Houde, Spatial Differentiation and Vertical Mergers in Retail Markets for Gasoline, 102 AM. ECON. REV. 47 (2012); Gregory S. Crawford et al., The Welfare Effects of Vertical Integration in Multichannel Television Markets, 86 ECONOMETRICA 891 (2018) (evidence that vertical integration of cable TV distributors with regional sports networks sometimes raised prices, even using lower bound estimates of harm). A recent working paper suggests that foreclosure often occurs, though it does not identify the specific matters. See Johannes Boehm \& Jan Sonntag, Vertical Integration and Foreclosure: Evidence from Production Network Data (December 8, 2018), https://jmboehm.github.io/foreclosure.pdf (suppliers more likely to break relationships with buyers when integrate with competitor of buyers, relative to integration with non-competitor).

${ }^{4}$ E.g., D. Bruce Hoffman, Acting Director, Bureau of Competition, Fed. Trade Comm'n, Vertical Merger Enforcement at the FTC 4 n.9 (Jan. 10, 2018),

http://www.ftc.gov/system/files/documents/public_statements/1304213/hoffman_vertical_merger_speech _final.pdf. 
merger with a firewall remedy, an outcome that was supported by Chairman Simons and Commissioners Wilson and Phillips. ${ }^{5}$ Commissioners Slaughter and Chopra dissented. ${ }^{6}$ In the Fresenius/NxStage matter, the Commission required divestiture to cure a small horizontal overlap, but the Commission majority did not find any vertical merger concerns from the combination. Commissioners Slaughter and Chopra again dissented. ${ }^{7}$

In neither case did the Commission release a redacted but detailed staff analysis of the mergers. As a result, the analysis in this article necessarily relies on the limited information contained in the statements by the Commissioners and some basic understanding of the markets, along with inferences drawn from the statements. The statements are all short. They briefly summarize some of the staff analysis but do not indicate very much about the staff's economic analysis, or enough to determine the economic support for certain conclusions. As a result, the analysis in this article should be treated as exploratory. I readily concede that my preliminary evaluations could turn out to be incorrect, in that it is based on what can be gleaned from the statements and the lack of more publically available evidence. Thus, while one primary goal of this article is to raise questions about the facts and the economic analysis carried out by the staff, the other primary goal is to encourage the Commission to release more information about the mergers they clear, including these two.

In addition to supplying some limited factual information about the markets and the evidence on which they relied, the Commissioners' statements possibly provide a window into their divergent views of enforcement that will be relevant to predicting future enforcement

\footnotetext{
${ }^{5}$ Sycamore Partners II, L.P., F.T.C. No. 181-0180 (Jan. 28, 2019) (Decision and Order). Staples, Inc., F.T.C. No. 181-0180 (Jan. 28, 2019) (Statement of Chairman Joseph J. Simons, Comm'r Noah Joshua Phillips, and Comm'r Christine S. Wilson) [hereinafter Staples Majority Statement]; Staples, Inc., F.T.C. No. 181-0180 (Jan. 28, 2019) (Statement of Comm'r Christine S. Wilson).

${ }^{6}$ Staples, Inc., F.T.C. No. 181-0180 (Jan. 28, 2019) (Dissenting Statement of Comm'r Rebecca Kelly Slaughter) [hereinafter Staples Slaughter Statement]; Staples, Inc., F.T.C. No. 181-0180 (Jan. 28, 2019) (Dissenting Statement of Comm'r Rohit Chopra) [hereinafter Staples Chopra Statement].

${ }^{7}$ Fresenius Medical Care AG, F. T. C. No. 171-0227 (Feb. 19, 2019) (Decision and Order). Fresenius Medical Care AG, F.T.C. No. 171-0227 (Feb. 19, 2019) (Statement of Chairman Joseph J. Simons, Comm'r Noah Joshua Phillips, and Comm'r Christine S. Wilson) [hereinafter Fresenius Majority Statement]; Fresenius Medical Care AG, F.T.C. No. 171-0227 (Feb. 19, 2019) (Dissenting Statement of Comm'r Slaughter) [hereinafter Fresenius Slaughter Statement]; Fresenius Medical Care AG, F.T.C. No. 171-0227 (Feb. 19, 2019) (Dissenting Statement of Comm'r Chopra) [hereinafter Fresenius Chopra Statement].
} 
decisions and possible revision of the vertical merger guidelines. It appears that the dissenting Commissioners may have been open to a broader range of competitive concerns. The dissenting Commissioners also may have placed a lower evidentiary bar on the required showing of harm to competition. This may have been the result of placing a weaker presumption of substantial efficiency benefits generally flowing from vertical mergers in concentrated markets. Or, it may have involved placing greater weight on the Section 7 incipiency standard. At the same time, the dissenting Commissioners may have applied a higher evidentiary bar to satisfy a showing of merger-specificity of claimed efficiencies, though this cannot be known for certain until explained by the Commissioners. What is known, however, is that these presumptions and associated evidentiary standards are key determinants of vertical merger enforcement. ${ }^{8}$

This article also discusses a private antitrust case attacking the consummated merger of Jeld-Wen and Craftmaster Manufacturing Inc. ("CMI") that was litigated and won by the plaintiff, Steves \& Sons ("Steves") in 2018. 9 This merger was both horizontal and vertical. But, the anticompetitive allegations were focused on the fact that Jeld-Wen and its major competitor were vertically integrated and the merger led to conduct that raised the cost of Jeld-Wen's downstream rivals, including Steves. The merger was cleared by the Department of Justice ("DOJ") in 2012 without a remedy, and the anticompetitive exclusionary conduct commenced in 2014. Thus, the DOJ decision appears to be a clear false negative.

There are some factual parallels among these three vertical merger matters that make it interesting to analyze them together. First, the foreclosure concerns raised by Steves in the JeldWen merger and the concerns raised by dissenters in the Staples/Essendant merger both involved the "Frankenstein Monster" scenario of input foreclosure. ${ }^{10}$ In the paradigmatic scenario, the upstream competitor(s) of the merging firm gain market power and raise their prices in response to the foreclosure behavior (e.g., a price increase or refusal to sell) by the upstream merging firm. The Jeld-Wen/CMI case involved a variant of the scenario, whereby the vertically integrated competitor announced its intention not to sell to unintegrated downstream rivals and this

\footnotetext{
${ }^{8}$ Jonathan B. Baker et. al., Five Principles for Vertical Merger Enforcement Policy (Mar. 12, 2019), https://scholarship.law.georgetown.edu/cgi/viewcontent.cgi?article=3166\&context=facpub

${ }^{9}$ Steves \& Sons, Inc. v. JELD-WEN, Inc., No. 3:16-CV-545 (E.D. Va. Dec. 14, 2018).

${ }^{10}$ Thomas G. Krattenmaker \& Steven C. Salop, Anticompetitive Exclusion: Raising Rivals' Costs to Achieve Power over Price, 96 YALE L.J. 209, 241-42 (1986).
} 
announcement thereby endowed the merged firm with additional market power. Both of these cases also emphasize the need for the agencies to investigate the entire range of possible anticompetitive theories.

DOJ may have cleared the Jeld-Wen/CMI merger because of a lack of complaints. It appears that there were no significant (if any) complaints by competitors to the Fresenius/NxStage merger. ${ }^{11}$ This raises the factual question of whether a paucity of buyer complaints is a reliable predictor that a merger will lack anticompetitive effects. Steves' failure to complain apparently flowed from a mistaken belief that a long-term contract, and continued competition by the other vertically integrated firm, provided sufficient protection. A lack of complaints about the Fresenius/NxStage merger by Fresenius' major competitor conceivably might have flowed from the anticipation by its major competitor that the merger would deter entry and lead to beneficial coordinated effects. Again, the statements do not provide sufficient information on this issue.

The false negative decision to clear the Jeld-Wen merger also supports the need for postmerger investigations of consummated mergers in close cases or where there are limited consent decrees. This issue was raised by Commissioner Slaughter in the Staples/Essendant merger. ${ }^{12}$ The majority agreed with the general point but expressed the concern that the Commission lacked the resources to do so. ${ }^{13}$

Finally, the Fresenius/NxStage merger raises the issue of whether horizontal merger enforcement focused solely on local downstream markets can lead unintendedly to buy-side market power in national input markets, market power that subsequently can raise barriers to entry. This type of issue also was raised in the proposed Comcast/Time Warner Cable merger.

This short article discusses these issues in more detail. Section II discusses Steves \& Sons litigation involving the Jeld-wen/CMI merger. Section III discusses the Commissioners' analysis of foreclosure and other issues in the Staples/Essendant merger. Section IV discusses the Commissioners' analysis of the vertical merger aspects in the Fresenius/NxStage merger. Section V offers some policy conclusions derived from this exploratory analysis.

\footnotetext{
${ }^{11}$ Fresenius Majority Statement, supra note 7, at 1-2.

${ }^{12}$ Staples Slaughter Statement, supra note 6, at 1,9.

${ }^{13}$ Staples Majority Statement supra note 5, at 6.
} 


\section{The Jeld-Wen/CMI Merger}

As noted in the Introduction, the private antitrust litigation against the Jeld-Wen/CMI merger provides an interesting variant of the basic "Frankenstein Monster" scenario of the incentives of competing upstream suppliers to raise prices in response to a foreclosure strategy by another upstream firm. This case involved a successful attack on the 2012 consummated merger between Jeld-Wen and CMI. ${ }^{14}$ CMI initially was created as the divestee to resolve competitive concerns arising from the (mostly) vertical merger of Masonite and Premdor in $2001 .{ }^{15}$ A private Section 7 action against the Jeld-Wen/CMI merger was brought by Steves \& Sons, an independent firm that purchased doorskins from Jeld-Wen as an input into the production of interior molded doors, where it competed with Jeld-Wen and Masonite. The case was litigated as a horizontal merger in doorskins, though the fact of Jeld-Wen's vertical integration was highly relevant to the economic analysis, as discussed below.

The complaint alleged that the relevant market was doorskins for interior molded doors, where Jeld-Wen and Masonite had post-merger market shares of 52\% and 48\% respectively after the CMI acquisition. ${ }^{16}$ Jeld-Wen and Masonite also had market shares in interior molded doors of approximately were $40 \%$ and $42 \%$ respectively. ${ }^{17}$ Steves' share of interior molded doors was approximately $7 \% .^{18}$ The interior molded doors were sold to builders and also to retailers like Home Depot. The pre-merger market structure is pictured below in Figure $1 .{ }^{19}$

\footnotetext{
${ }^{14}$ On February 15, 2018, the jury found that the merger violated Section 7 of the Clayton Act. JELDWEN Announces Jury Verdict in Steves \& Sons Lawsuit, Business Wire, Feb. 15, 2018, https://www.businesswire.com/news/home/20180215006484/en/JELD-WEN-Announces-Jury-VerdictSteves-Sons-Lawsuit. The court subsequently denied Jeld-Wen's motion for a JNOV. Steves \& Sons, Inc. v. JELD-WEN, Inc., No. 3:16-CV-545 (E.D. Va. Dec. 14, 2018).

15 The 2001 merger of Masonite and Premdor created a vertically integrated competitor to Jeld-Wen. The DOJ required the divestiture of Masonite's Towanda doorskin facility, which created CMI. Competitive Impact Assessment at 4, 8, U.S. v. Premdor, No. 1:01CV01696 (D.D.C. Oct. 3, 2001). I consulted with Masonite's attorneys on this matter.

${ }^{16}$ Complaint at 977 , Steves \& Sons, Inc. v. JELD-WEN, Inc., No. 3:16-CV-545 (E.D. Va. Jun. 29, 2016). [hereinafter Complaint]. These market shares include both captive and merchant market sales.

${ }^{17} \mathrm{Id}$. at $\mathbb{1 7 7 .}$

${ }^{18} I d$.

${ }^{19} \mathrm{CMI}$ also produced molded doors. For simplicity, these door sales are not shown in Figure 1.
} 


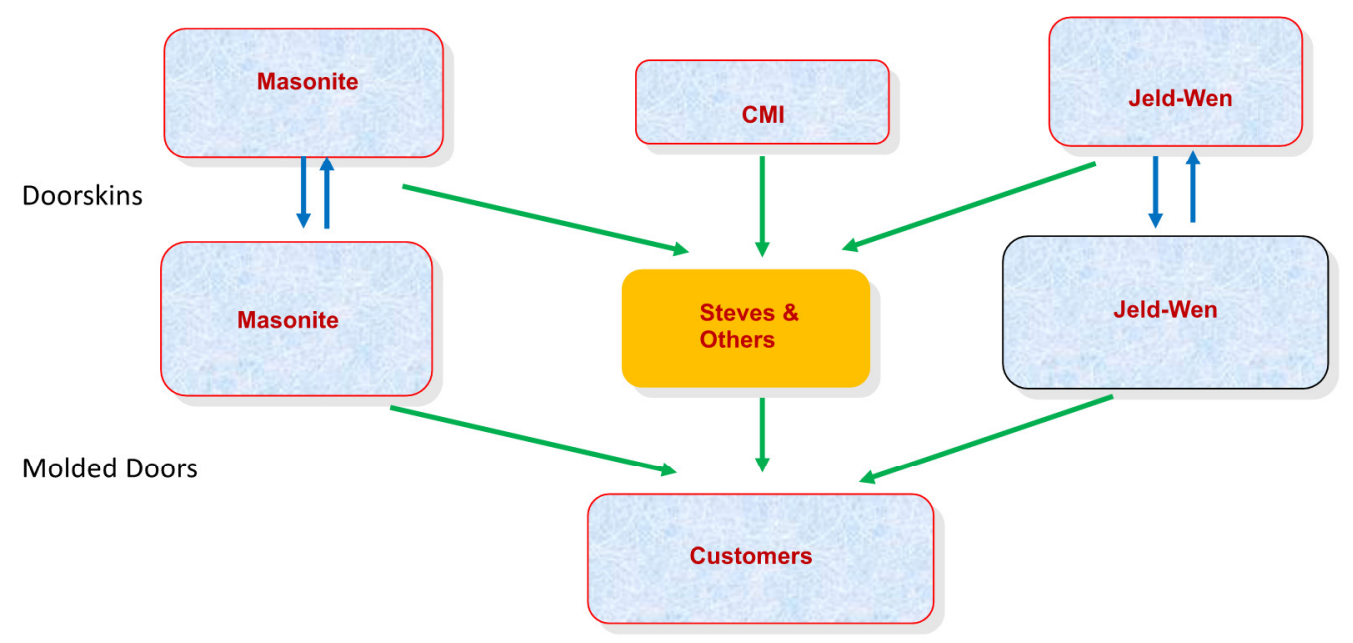

Figure 1: Jeld-Wen/CMI Market Structure

The DOJ cleared the Jeld-Wen/CMI merger without a remedy. When the proposed merger was investigated by the DOJ, Steves apparently did not complain, likely because it had negotiated a long-term year contract with Jeld-Wen shortly before Jeld-Wen announced the CMI acquisition. ${ }^{20}$ Steves also may have mistatenly relied on continued doorskins competition from Masonite. However, in June 2014, there was a key development that led to the anticompetitive allegations. Masonite announced publicly that it would no longer supply doorskins to unintegrated firms. ${ }^{21}$ The announcement stated the following:

Only Masonite and JELD-WEN service the entire North American market. And other door assembly companies are smaller and much more regionally focused. And importantly, the other smaller. . . door assembly manufacturers have to get their facings [i.e., doorskins] from somebody else. They're not vertically integrated in their facings. And we, at Masonite, have determined that we will not

${ }^{20} I d$. at I59; Memorandum Opinion at 5, Steves \& Sons, Inc. v. Jeld-Wen, Inc., No. 3:16-cv-545 (E.D. Va. Feb. 9 2018) [hereinafter, Memorandum Opinion]. The supply contract was signed on May 1, 2012. Complaint, supra note 16, at II1. The letter of intent to acquire CMI was announced on June 18, 2012. See Steves \& Sons, Inc v. Jeld-Wen, Inc., 252 F.Supp.3d 537 (E.D. Va. 2017).

${ }^{21}$ Complaint, supra note 16 , at $\Phi[23$. 
sell our facings into- - to competition. So, that only leaves one other outlet for them to get their facings from in North America. ${ }^{22}$

About two weeks later, Jeld-Wen's CEO sent Steves a copy of the Masonite presentation, characterizing it as "a very informative document for our discussions."23 In August 2014, JeldWen and Masonite implemented price increases for doors of $9.5 \%$ and $8 \%$ respectively. ${ }^{24}$ In October 2014, Jeld-Wen gave Steves notice that it would terminate their supply agreement when it expired. ${ }^{25}$ This was followed by $5 \%$ price increases implemented in March $2015{ }^{26}$

Steves' anticompetitive theory is a type of "Frankenstein Monster" scenario. ${ }^{27}$ By announcing that it would not supply unintegrated firms like Steve's with doorskins, Masonite endowed Jeld-Wen with monopoly power. ${ }^{28}$ Jeld-Wen no longer needed to worry about losing business to Masonite. Jeld-Wen then exercised that monopoly power to raise the costs of their common unintegrated competitor in the doors market. These higher prices of doorskins sold to Steves and other independents would allow both Masonite and Jeld-Wen to raise their molded door prices as well. These downstream price increases provide the anticompetitive motivation for Masonite to make the announcement. Masonite would have no other incentive to give JeldWen market power in the doorskin market. This analysis-and the fact that the evidence shows that the price increases occurred — shows how vertically integrated firms can implement foreclosure strategies that rely on responsive price increases by rivals. This anticompetitive theory is pictured in Figure 2 below.

${ }^{22} I d$. at $\llbracket 95$.

${ }^{23} I d$. at $\Phi[97$.

${ }^{24} I d$. at 9991.

${ }^{25} I d$. at $9[98$. Jeld-Wen apparently initially announced a termination date in 2019 , but subsequently conceded that the termination would have to wait until 2021.

${ }^{26} I d$. at 990 .

${ }^{27}$ Krattenmaker \& Salop, supra note 10, at 240-242. The Frankenstein Monster theory is normally an issue in vertical mergers. Since this matter involves a horizontal acquisition in a market where the two leading firms are vertically integrated, it arises naturally here as well.

${ }^{28}$ Complaint, supra note 16 , at $\operatorname{TII} 23,76$. 


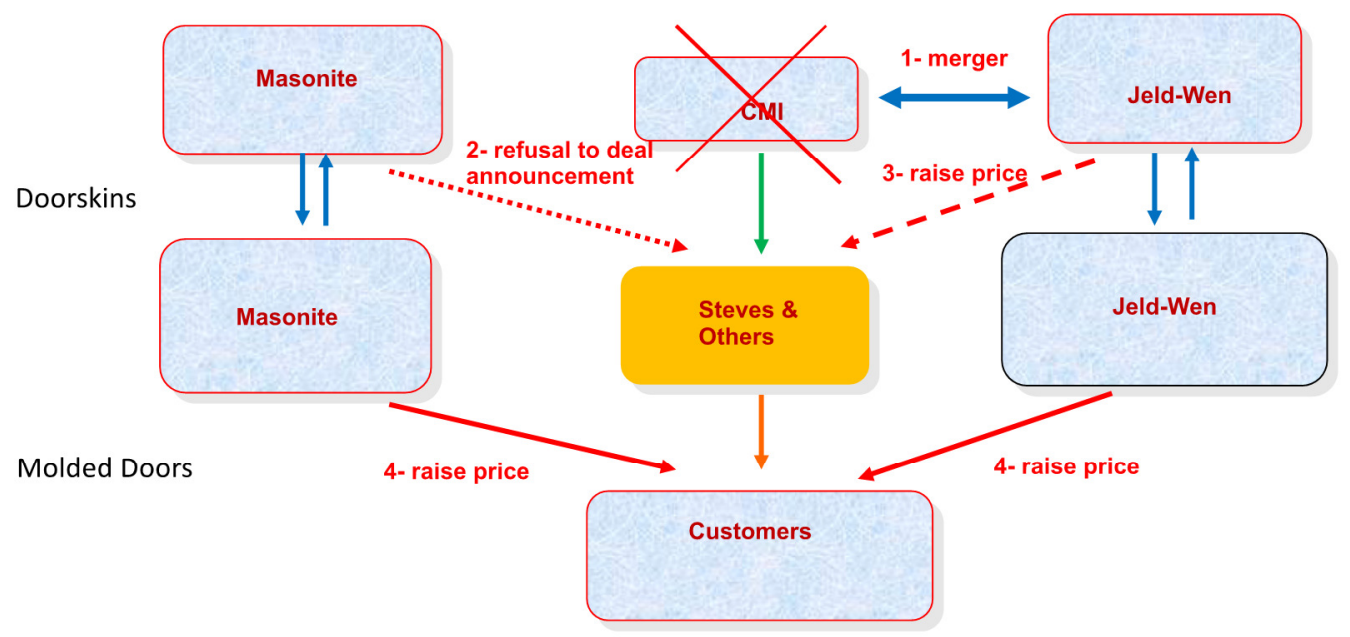

Figure 2: CMI Acquisition \& Frankenstein Monster

Steves' economic expert, Professor Carl Shapiro, analyzed the anticompetitive effects along these lines. ${ }^{29}$ By contrast, Jeld-Wen's economic expert, Professor Edward Snyder, argued that there was no anticompetitive effect because output (the number of interior molded doors sold in the United States) increased in the years following the merger. ${ }^{30}$ Professor Shapiro explained in response that following the merger in 2012, the housing market recovered substantially from the Great Recession. ${ }^{31}$ He further noted out that a several dollar increase in the price of doors (or doorskins) likely would not reduce the number of doors in a new house being built or home being remodeled. ${ }^{32}$

${ }^{29}$ Transcript of Trial Proceedings at 97-103, Steves \& Sons, Inc. v. Jeld-Wen, Inc., No. 3:16-cv-545 (E.D. Va. Feb. 21 2018), ECF No. 1031.

${ }^{30}$ Transcript of Trial Proceedings at 224-28, Steves \& Sons, Inc. v. Jeld-Wen, Inc., No. 3:16-cv-545 (E.D. Va. Feb. 21 2018), ECF No. 1316.

${ }^{31}$ Transcript of Trial Proceedings at 100-02, Steves \& Sons, Inc. v. Jeld-Wen, Inc., No. 3:16-cv-545 (E.D. Va. Feb. 21 2018), ECF No. 1036.

${ }^{32} I d$. at 101. 
The jury held for Steves and the judge has ordered divestiture. (Jeld-Wen has filed a motion for a new trial and announced it will appeal the judgment if the motion is dismissed. ${ }^{33}$ ) This successful private litigation suggests that clearing the Jeld-Wen/CMI merger was a false negative. This raises two questions about the DOJ's decisions. First, why did the DOJ clear the Jeld-Wen/CMI merger in 2012 when it was proposed? Second, why did the DOJ itself fail to bring a subsequent case against the consummated merger after the Masonite announcement and the price increases by Jeld-Wen and Masonite.

The DOJ should have been suspicious of the Jeld-Wen merger proposal. After all, CMI was formed from the required divestiture following the Masonite-Premdor merger. If the formation of CMI was necessary to provide a competitive constraint to Masonite and Jeld-Wen in 2001, why did it cease to be necessary a decade later? One possibility could be that CMI was successful in forcing Masonite and Jeld-Wen to set low "limit prices," while failing to get much business itself because its costs were higher. As a result, CMI might have looked relatively unsuccessful to investors and possibly to the DOJ too. But removing this perceived pricing constraint nonetheless likely would lead to price increases. It would be interesting to learn whether the DOJ overlooked this point.

As suggested above, an attack on the Jeld-Wen/CMI merger might have been saddled by the lack of complaints by Steves and others. This raises the question of whether lack of buyer complaints is a reliable predictor that a merger will not be anticompetitive. In this matter, Steves' failure to complain apparently flowed from a mistaken belief that it would be protected by a combination of the long-term contract with Jeld-Wen. It may also have mistakenly assumed that there would be continued competition between Masonite and Jeld-Wen. Thus, this case illustrates the point that the beliefs of buyers may be inaccurate.

This inaccuracy is not a novel idea. Recall that buyers' beliefs that a merger would be anticompetitive were rejected by Judge Walker in the Oracle/PeopleSoft litigation in 2004. ${ }^{34}$ The failure of many buyers to complain was raised by Bazaarvoice in the DOJ's 2014 litigation

\footnotetext{
${ }^{33}$ Drew Vass, After Final Ruling, Jeld-Wen and Steves Continue to Spar, DoOR \& WINDOW MKT. MAG. (Feb. 11, 2019), https://www.dwmmag.com/after-final-ruling-jeld-wen-and-steves-continue-to-spar/.

${ }^{34}$ United States v. Oracle Corp., 331 F. Supp. 2d 1098 (N. Dist. Cal. 2004).
} 
attacking the acquisition of PowerReviews by Bazaarvoice. ${ }^{35}$ In this latter case, Judge Orrick agreed with the DOJ's economic expert, Professor Carl Shapiro, that the views of the buyers were not the best sources of information about the effect of the merger. ${ }^{36}$ After all, the buyers would not have access to the documents of the merging firms.

I do not know why the DOJ failed to bring its own case against the Jeld-Wen/CMI merger, once it became apparent that the long-term contracts and competition from Masonite were inadequate constraints on Jeld-Wen's pricing power. One possibility could be lack of resources. Perhaps the DOJ thought that Steves was well-equipped to bring its own case, so the incremental benefit from having a DOJ case would be less than the agency's resource cost. Another possibility rooted in human nature might be that people and agencies could be reluctant to recognize their mistakes. ${ }^{37}$ Of course, we would like enforcement agencies to take steps to avoid such defensive behavior.

\section{The Staples/Essendant Merger}

This vertical merger involved the acquisition by a retail seller (Staples) of a major wholesale supplier (Essendant) in the market for sale and distribution of office products to midmarket business-to-business customers. While the Commissioners' statements unfortunately do not provide much factual analysis, it appears that the upstream wholesale market was highly concentrated with the two main competitors being Essendant and SP Richards. The downstream market (retailing) involved numerous dealers and Staples apparently had only a modest market share of the business customers of those dealers. This pre-merger market structure is summarized in Figure 3 below. My understanding is that Staples did not purchase from Essendant before the merger. But I assume that Staples would combine purchases with Essendant from manufacturers after the merger, which might lead to lower costs from higher purchase volume. $^{38}$

\footnotetext{
${ }^{35}$ Memorandum Opinion, United States v. Bazaarvoice, Inc., No. 13-cv-00133 (N. Dist. Cal. Jan. 8, 2014).

${ }^{36} I d$. at 8 .

${ }^{37}$ This point also has implications for merger retrospective studies. See infra Section V.

${ }^{38}$ Staples Majority Statement, supra note 5 at 2 . The majority also says that the lower prices will not involve monopsony power. These costs savings are not elimination of double marginalization because
} 


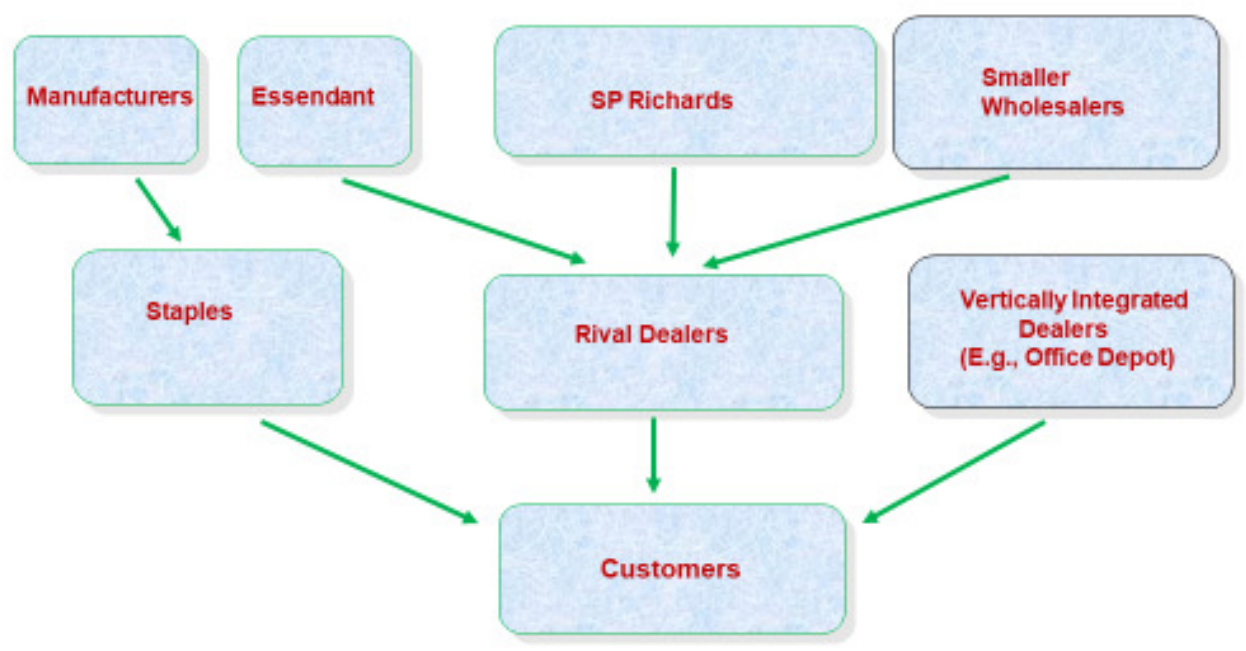

Figure 3: Staples/Essendant Pre-Merger Market Structure

The Statement of the three Commissioners ("Majority") who voted to clear the merger explains that the primary potential harm analyzed and rejected was input foreclosure.

The primary theory of harm that was considered and rejected involves Staples potentially raising Essendant's prices. This hypothetical conduct potentially would force Essendant's independent dealer customers to raise prices to their customers - the mid-sized businesses - some of whom would presumably look for other suppliers. Staples would lose money from whatever sales Essendant lost due to its higher prices. But if enough businesses that switched sales away from the independent dealers decided to buy from Staples, in theory, the overall strategy could be profitable. ${ }^{39}$

The Majority rejected this foreclosure theory on the grounds that if Essendant raised tis prices, its independent dealer-customers would switch away from Essendant and instead would purchase mainly from its competitor, SP Richards (“SPR"). ${ }^{40}$ Because the dealers' costs would

the manufacturers would continue to charge a margin to Essendant, just as they did to Staples. But the margin might be lower because of the higher purchase volume.

${ }^{39}$ Staples Majority Statement, supra note 5, at 1.

${ }^{40} I d$. at 2. 
not be raised, there would be little diversion by the business customers of those dealers to Staples, which in turn would make the hypothetical Essendant price increase unprofitable.

This discussion of the stated rationale for the low diversion to Staples appears to assume that SPR would not raise its own prices in response to the Essendant price increase. By contrast, Commissioner Slaughter suggested that SPR would have the incentive to raise its prices. ${ }^{41}$ If SPR were to accommodate the Essendant price increase with its own price increases, it would follow that the diversion to Staples would be larger, which would make the Essendant price increase more profitable for the merged firm. There also would be harms to the dealer customers of SPR from these price increases and competitive harms to their business customers.

Because the wholesale market is highly concentrated, economic analysis would suggest that SPR would have the incentive to accommodate the Essendant price increase by raising its own prices. SPR might not have the incentive to exactly match the price increase, but it would have the incentive to at least partially to accommodate it. In this way, the vertical merger could facilitate imperfect coordination in the upstream market. In fact, SPR might lead the post-merger price increase, knowing the Essendant would have the incentive to follow. Either way, the diversion to Staples would be much larger.

This foreclosure theory is summarized in Figure 4 below. For completeness, the Figure includes the possibility that there were other vertically integrated dealers, such as Office Depot, competing in the market. Because these competitors are not mentioned by the Commissioners, this analysis assumes that potential diversion to these other competitors would not have eliminated the competitive concerns.

\footnotetext{
${ }^{41}$ Staples Slaughter Statement, supra note 6, at 8.
} 


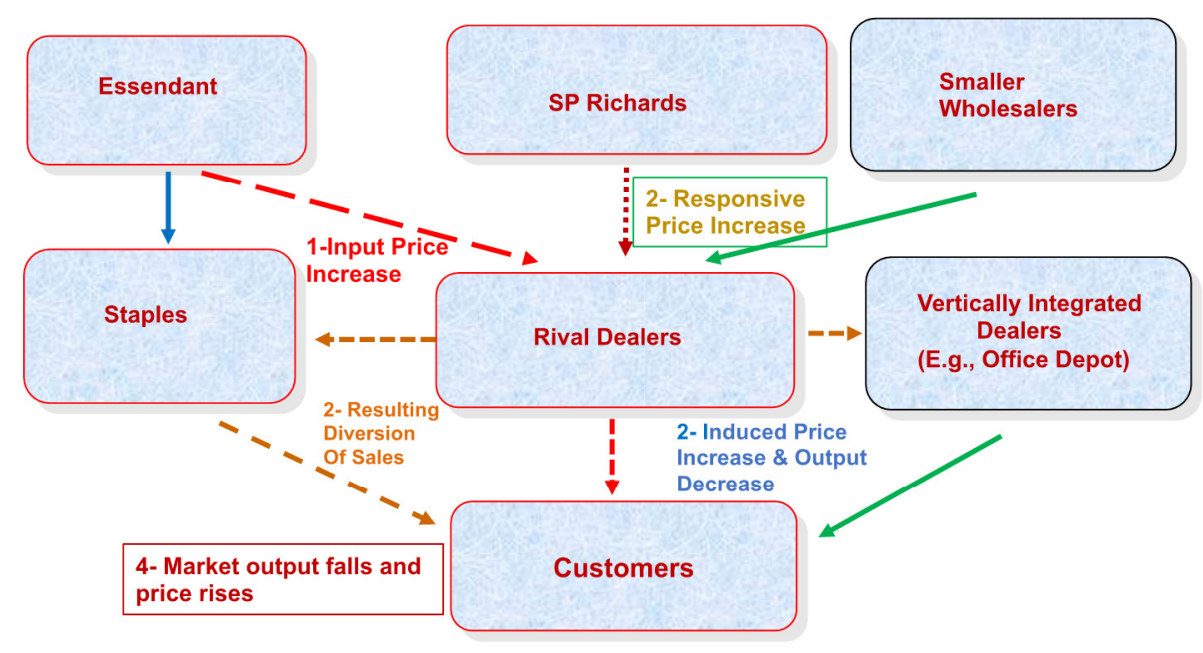

Figure 4: Staples Input Foreclosure Theory

Commissioner Slaughter's concern thus involved the Frankenstein Monster scenario. The Essendant price increase would endow SPR with additional market power and SPR then would have the incentive to raise its own wholesale prices. SPR's incentive to accommodate the Essendant price increase (or even lead the price increase itself in anticipation of Essendant's post-merger pricing incentives) follows from conventional economic analysis that a unilateral price increase by one large differentiated product firm will incentivize its substantial competitors also to raise their own prices in response. This reasoning also is embedded in the 2010 Horizontal Merger Guidelines discussion of coordination through parallel accommodating conduct. $^{42}$ The same incentive of a large oligopoly input market competitor to raise its own prices also applies to vertical mergers. ${ }^{43}$ If the other upstream suppliers also raise their input prices, this will raise the costs of the downstream rivals of the merging firm, which can in turn lead to higher prices paid by the business customers of all the dealers.

\footnotetext{
${ }^{42}$ U.S. DeP'T OF Justice \& Fed. TRAde COMM’N, Horizontal MERGER Guidelines 24-25 (2010) [hereinafter MERGER GUIDELINES], https://www.ftc.gov/sites/default/files/attachments/mergerreview/100819hmg.pdf.

${ }^{43}$ Krattenmaker \& Salop, supra note 10, at 241-42.
} 
The majority statement does not explain why SPR would lack this incentive to accommodate Essendant price increases. It merely says that the evidence did not show that there would be sufficient switching to Staples by Essendant's dealer customers dealers because of Staples' low share in the downstream market, and the differentiation between the services Staples and the wholesalers provide ${ }^{44}$ However, it does not discuss why diversion to Staples would remain insubstantial if SPR also raised its prices, as suggested by Commissioner Slaughter. ${ }^{45}$ Nor does it explain why Essendant would fail to raise its prices in anticipation of SPR following. ${ }^{46}$ These are key missing elements. If there is no credible countervailing evidence, then the decision to reject the theory of competitive harm possibly could be a false negative. ${ }^{47}$ However, absent further facts or analysis from the Commissioners or the staff, this conclusion remains uncertain. Thus, it seems important for the Commission to explain why it rejected this version of the anticompetitive theory.

The incentive of SPR to raise its prices could be reinforced by another possible fact. After the merger, some dealers may become reluctant to purchase from Essendant because of its

\footnotetext{
${ }^{44}$ Staples Majority Statement, supra note 5, at 2, 4.

${ }^{45}$ Commissioner Slaughter interprets the staff analysis to imply that substitution to SPR would be lower because of switching costs. The Majority disagreed that there were switching costs, however, saying that some dealers bought from both suppliers and others switched between them. Staples Majority Statement, supra note5, at 2. If there were switching costs, additional analysis would be required because those costs existed in the pre-merger world too, so they might have already been incorporated into prices. But not necessarily. Staples might not have been able profitably to raise price because it would fear that it would not attract as many new customers. But after the merger, Staples would be less concerned with not attracting new customers if SPR also raised price, and so, it would be more prone to exploit the captive customers. This is similar to the analysis of installed base opportunism in Kodak. See Steven C. Salop, The First Principles Approach to Antitrust, Kodak, and Antitrust at the Millennium, 68 ANTITRUST L. J 187, 191-94 (2000); Carl Shapiro, Aftermarkets and Consumer Welfare: Making Sense of Kodak, 63 AnTitrust L.J. 483, 488 (1995); Post-Chicago Analysis After Kodak: Interview with Professor Steven C. Salop, 7 ANTITRUST 20, 21 (1992).

${ }^{46}$ One possibility is that the business customers of SPR's dealer-customers would not switch to Staples if all of SPR's dealers raised their prices, but would switch to other dealers. This is not discussed in the statements. The majority statement does suggest that Staples was a weaker substitute for business customers than were these various high-touch dealers. Staples Majority Statement, supra note 5, at 2. But it does not explain why Staples would be remain a distant substitute if all those high-touch dealers had higher prices from facing higher wholesale prices charged by both SPR and Essendant.

${ }^{47}$ The majority did not rest its decision on efficiencies. But if the claimed efficiencies were verifiable, merger-specific and sufficient to reverse these price increases, then the decision to clear might not have been a false negative.
} 
ownership by Staples. This behavior would have the effect of making SPR's demand more inelastic, which would give it an increased incentive to raise prices. Commissioner Slaughter makes this point that "SPR ... may be able to charge higher prices to resellers looking to avoid a relationship with Staples." 48

This switching behavior could have two causes. One possibility is that the dealers might rationally fear that their confidential information would be obtained by Staples despite the Commission's firewall remedy. ${ }^{49}$ In this regard, Commissioner Chopra expressed the concern that the firewall likely would be penetrable. ${ }^{50}$ The Majority joined issue with this concern and responded that the firewall would not be penetrated, relying on the recent FTC Remedy report that indicated that the firewalls in four unidentified vertical merger consent decrees were found to be "robust." ${ }^{51}$ However, it is not clear that this FTC report would provide sufficient reassurance to those dealers.

A second possibility is that the dealers might prefer not to purchase from Essendant after the merger simply because they may simply not want to aid their competitor. This behavior was famously observed in the fast food market after PepsiCo acquired some franchises. ${ }^{52}$ This possibility was not discussed in the statements.

${ }^{48}$ Staples Slaughter Statement, supra note 6, at 8.

${ }^{49}$ In a bargaining model, this dealer fear would increase SPR's bargaining leverage, thereby allowing it to negotiate higher prices.

${ }^{50}$ Staples Chopra Statement, supra note 6, at 5.

${ }^{51}$ Staples Majority Statement, supra note 5, at 3 n.8 (citing FED. TRADE COMM'N, THE FTC's MERGER REMEDIES 2006-2012: A REPORT OF THE BUREAUS OF COMPETITION AND ECONOMICS (2017), https://www.ftc.gov/system/files/documents/reports/ftcs-merger-remedies-2006-2012-report-bureauscompetition-economics/p143100_ftc_merger_remedies_2006-2012.pdf). However, the analysis set out in the report was limited. The report analyzed four vertical mergers. It does not explain how a compliance monitor would be able to detect firewall breaches, particularly those that occurred orally. It also does not explain how the competitors or buyers would know that firewalls were not breached.

${ }^{52}$ Pepsico's aquired Kentucky Fried Chicken (in 1986), Taco Bell (in 1978) and Pizza Hut (in 1977). The ownership spurred some other fast food chains to abandon PepsiCo for Coca Cola because they did not want to aid their competitor. Pepsico spun off these brands in 1997. See Glen Collins, Pepsico to Spin Off its Fast-Food Business, N.Y. TIMES (Jan. 24, 1997), https://www.nytimes.com/1997/01/24/business/pepsico-to-spin-off-its-fast-food-business.html. 
The focus of the majority statement was low diversion to Staples in the event that Essendant raised its prices. The majority statement did not discuss the potential that the merger would give Staples an incentive to raise its prices. If Staples raised its prices and this caused diversion from Staples to the dealers that purchased inputs from Essendant, then the merger would create a benefit to Essendant that the merged firm would take into account. ${ }^{53}$ While most business customers that desired high-touch dealers might not prefer Staples, the customers that do not require high-touch dealers still might switch to them if Staples raised its prices. Again, more facts would be needed to understand and evaluate the staff analysis of this issue.

Another provocative issue was Commissioner Chopra's suggestion that private equity firms like Sycamore Partners have an interest in setting higher prices than Essendant would. ${ }^{54}$ The Majority responded that the pricing policies of private equity firms is not a standard "competitive effect" cognizable under Section 7 because it would occur even if the merger were neither vertical nor horizontal. ${ }^{55}$ Commissioner Chopra did not respond to this important counter. It is interesting that this disagreement over whether the scope of Section 7 includes general corporate pricing policies is not new at the FTC, but arose in the Lundbeck acquisition of Indocin in 2008. ${ }^{56}$ What is perhaps different here is that the corporate pricing policy in this case

\footnotetext{
${ }^{53}$ If there were merger-specific efficiencies, it would mitigate or even reverse this upward pricing pressure.

${ }^{54}$ Staples Chopra Statement, supra note 6, at 3.

${ }^{55}$ Staples Majority Statement, supra note 5, at 4-5.

${ }^{56}$ In this matter, Commissioners Rosch and Liebowitz argued that prices would rise after Lundbeck purchased Indocin from Merck, despite the fact that that the merger was neither vertical nor horizontal. Their concern was that the acquisition would eliminate reputational constraints on raising prices that would apply to the seller (Merck) but would not apply to the acquirer (Lundbeck). Concurring Statement of Commissioner J. Thomas Rosch, FTC v. Ovation Pharmaceuticals, Inc., FTC File No. 0810156 (Dec. 16, 2008), https://www.ftc.gov/system/files/documents/public_statements/418091/081216ovationroschstmt.pdf; Concurring Statement of Commissioner Jon Leibowitz, FTC v. Ovation Pharmaceuticals, Inc., FTC File No. 0810156 (Dec. 16, 2008), https://www.ftc.gov/sites/default/files/documents/public_statements/concurring-statement-commissionerjon-leibowitz-re-federal-trade-commission-v.ovation-pharmaceuticalsinc./081216ovationleibowitzstmt.pdf ("I would have supported the approach proposed by Commissioner Rosch." See also, J. Thomas Rosh \& Darren S. Tucker, Emerging Theories of Competitive Harm in Merger Enforcement, ANTITRUST SOURCE (Oct. 2011), https://www.americanbar.org/content/dam/aba/publishing/antitrust_source/oct11_rosch_oct24f.authcheck dam.pdf.
} 
arguably would magnify conventional anticompetitive incentives for input foreclosure rather than provide an independent rationale for attacking the merger. But, this latter issue was not debated in the statements.

Finally, Commissioner Slaughter also suggested that the Commission adopt a regular practice of retrospective investigations of close-call mergers that were not challenged and retain the option of challenging the consummated mergers, if anticompetitive effects subsequently were found. ${ }^{57}$ The false negative in the Jeld-Wen/CMI merger suggests the benefit of continued vigilance in such matters. The Majority does not seem to disagree in principle, but stressed that the Commission had limited resources and using more resources on retrospectives could interfere with ongoing enforcement. Some policy implications flowing from the triage required by this resource scarcity are discussed in the Conclusions. ${ }^{58}$

\section{The Fresenius/NxStage Merger}

This merger involved both horizontal and vertical merger elements. ${ }^{59}$ I begin with a general overview of the market, albeit based on limited information. In the U.S., kidney hemodialysis is carried out at hospitals but mainly at standalone outpatient clinics. Fresenius and DaVita together account for about $85 \%$ of outpatient hemodialysis patients. ${ }^{60}$ After an initial period in which private insurers cover treatment, kidney hemodialysis is paid for by Medicare at regulated prices. There may have been no price competition for the Medicare patients, though there can competition be for the privately insured patients, including arrangements with nephrologists. ${ }^{61}$ There also could be quality competition. My understanding is that while it faces some competition, Fresenius dominates the sale of hemodialysis equipment, which it also sells to competing outpatient clinic operators such as DaVita as well as to hospitals.

${ }^{57}$ Commissioner Slaughter also proposed to use this process for mergers with limited consent decrees. Staples Slaughter Statement, supra note 6, at 5. See also Steven C. Salop, Modifying Merger Consent Decrees: An Economist Plot to Improve Merger Enforcement Policy, 31(1) ANTITRUST 15 (2016).

${ }^{58}$ Infra Section V.

${ }^{59}$ Fresenius Majority Statement, supra note 7; Fresenius Slaughter Statement supra note 7; Fresenius Chopra Statement, supra note 7.

${ }^{60}$ Fresenius Chopra Statement, supra note 7, at 3.

${ }^{61}$ If Medicare reimbursements depend on market rates, then price competition for privately insured patients would spillover to Medicare too. 
It is possible for a patient to undergo hemodialysis at home. In-home hemodialysis has the advantage of treatment at home overnight while sleeping. ${ }^{62}$ Its disadvantage is the need to take a more active role, including dealing with the blood, and cleaning the machine. Only 1-2\% of U.S. patients use in-home hemodialysis, but it apparently is much more prevalent elsewhere. ${ }^{63}$ Fresenius produces an in-home machine ("Baby K") that has gained little traction. ${ }^{64}$

Figure 5 summarizes the market structure without NxStage. The Figure treats clinical and in-home outpatient hemodialysis services as competing in an overall hemodialysis outpatient services market. Fresenius is treated as the dominant provider of hemodialysis machines in the upstream market, facing only fringe rivals. For simplicity, the "bubble" for fringe outpatient clinics are not shown in the Figure.

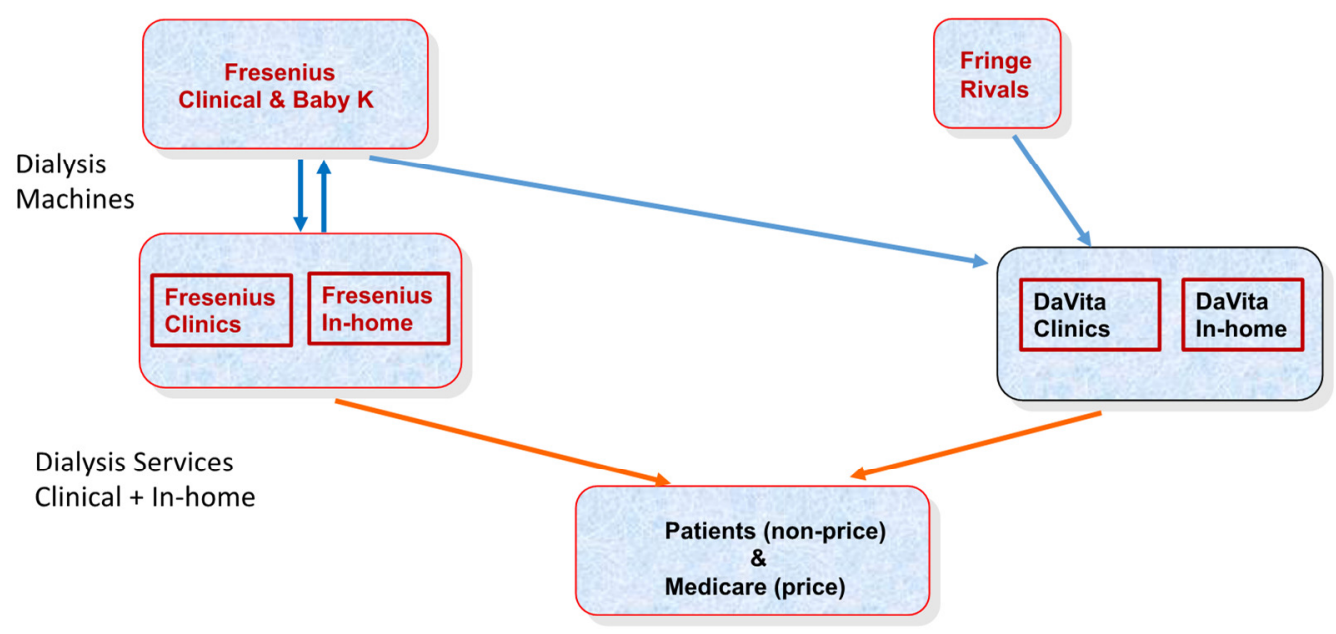

Figure 5: Dialysis Market Structure (Pre-NxStage)

NxStage obtained FDA approval for its innovative next-generation machine in 2005. Its machine can be used in a clinical setting and NxStage had established a small number of clinics.

${ }^{62} I d$. at 2.

${ }^{63}$ In-home dialysis is more common elsewhere. For example, Commissioner Chopra states that it covers almost $20 \%$ of patients in New Zealand. Fresenius Chopra Statement, supra note 7, at 2.

${ }^{64}$ Fresenius Majority Statement, supra note 7, at 2. 
The NxStage machine also apparently also has a large advantage in that it would be less expensive and more convenient to install at home than the Baby-K. However, my understanding is that the NxStage machine has made little headway in the market, either in sales to existing clinics or to new independent providers of in-home care.

Figure 6 shows how the successful large-scale entry of NxStage could dramatically change the market structure and performance. First, if its equipment is sufficiently high quality, NxStage might create significant upstream competition that could benefit DaVita and the smaller clinics by providing an innovative substitute for Fresenius' machines. Second, and potentially more important, NxStage's entry could create significant new competition against both Fresenius and DaVita clinics by independent in-home service providers. Third, NxStage could provide a way for Fresenius (and DaVita) to grow their in-home business as a supplement to their clinical services. Only this third effect was discussed in the majority statement.

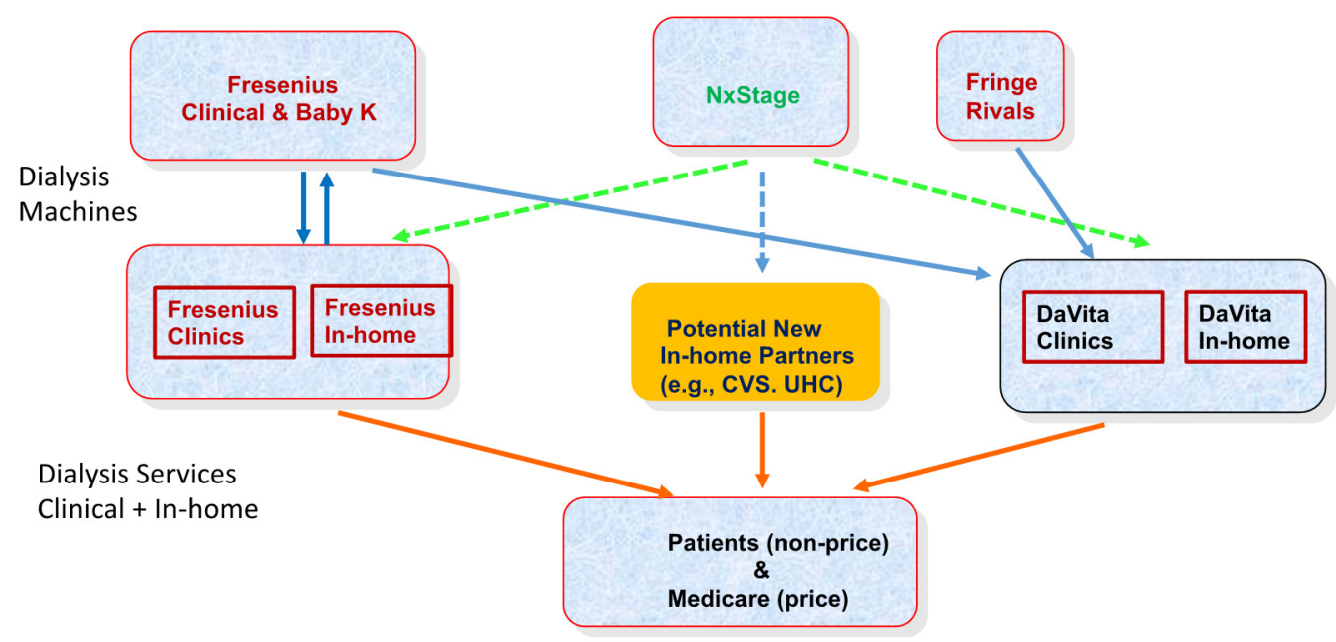

Figure 6: Dialysis Market Structure (Including NxStage)

By acquiring NxStage, Fresenius eliminates this actual and potential competition from NxStage in the equipment market and entrench Fresenius' dominance market. While the majority did not discuss this issue, it was raised by Commissioners Chopra and Slaughter. ${ }^{65}$ This

\footnotetext{
${ }^{65}$ Fresenius Chopra Statement, supra note 7, at 4; Fresenius Slaughter Statement, supra note 7, at 1.
} 
analysis raises several questions. First, why did DaVita fail to outbid Fresenius for NxStage as a way to undo this dominance? Second, in light of this entrenched dominance, did DaVita complain to the FTC about the acquisition; and if not, why not? Third, why was the competitive impact in the equipment market not more central to all the Commissioners' statements?

The statements do not mention whether or not DaVita was a bidder for NxStage. Such bidding competition might have been expected in that DaVita is currently reliant on Fresenius for its hemodialysis machines and Fresenius presumably is charging prices reflecting its market power. However, these same facts suggest that Fresenius likely would have the economic incentive to outbid DaVita for NxStage. Longstanding economic analysis explains that a monopolist would have the incentive to bid higher in order to maintain its monopoly profits, whereas the bidding competitor would only achieve duopoly profits. It is easy to show that as long as monopoly profits exceed the combined duopoly profits, the monopolist normally will win the bidding competition. ${ }^{66}$ It even is possible that DaVita would choose to forgo the cost of engaging in a bidding competition, anticipating that it would inevitably lose in the end.

The statements do not indicate that DaVita complained about Fresenius acquiring NxStage, despite the impact of the merger in maintaining Fresenius' dominance of the equipment market. If it did not complain, one possible explanation is that DaVita feared retaliation if it did complain. Another possible explanation could be that Fresenius and DaVita struck a long-term contract for Fresenius to supply the NxStage machines to DaVita. Fresenius currently supplies DaVita and others and the majority concludes that Fresenius would supply the NxStage machine to rivals, though it does not discuss the price level. ${ }^{67}$

A third possible explanation could be that DaVita preferred that Fresenius acquire NxStage rather than someone else. This is because Fresenius could prevent in-home

\footnotetext{
${ }^{66}$ For example, suppose monopoly profits are $\$ 200$ and duopoly profits are $\$ 70$ each, for a total of $\$ 140$. The competitor would have the incentive to bid up to $\$ 70$, whereas the monopolist would have the incentive to bid up to $\$ 130$ (i.e., \$200 - \$70). For further details, see, e.g., Steven C. Salop, The Raising Rivals' Cost Foreclosure Paradigm, Conditional Pricing Practices and the Flawed Incremental PriceCost Test, 81 ANTITRUST L.J. 371, 408-10. This same analysis explains why a branded pharmaceutical producer and the only generic entrant would have the incentive to strike an agreement that pays the generic entrant to delay its entry.

${ }^{67}$ Fresenius Majority Statement, supra note 7.
} 
hemodialysis from threatening the DaVita and Fresenius duopoly. Perhaps this was a so-called "killer acquisition," whose primary purpose is to eliminate or control an innovative competitor.

This "killer acquisition" interpretation can be explained as follows. In-home hemodialysis competes with outpatient clinic hemodialysis, at least for some patients. Thus, Fresenius and DaVita each might have little incentive to create an alternative to their profitable outpatient clinics in the pre-merger world. ${ }^{68}$ They also would have little interest in purchasing NxStage machines in the pre- merger world even at favorable prices. If they helped grow NxStage's in-home dialysis service, it could lead to competition by specialized service providers that patients' nephrologists could recommend. This could be a serious competitive threat to the Fresenius and DaVita clinics.

Since NxStage might have had a chance to partner with independent service providers in the future, a possible merger motivation could be a strategy to gain control over this disruptive next-generation technology. In this sense, the merger is fundamentally horizontal-a way to prevent independent competition in providing in-home hemodialysis services.

The majority statement does not explicitly discuss and reject this possible killer acquisition motivation. One possible reason for its inapplicability could be that NxStage essentially was doomed to failure because Fresenius and DaVita showed little interest in helping in-home hemodialysis to grow and they could successfully tacitly (and legally) coordinate not to promote the NxStage product. And while NxStage in principle could have entered both levels, perhaps it lacked sufficient expertise at the downstream level and was unable to find or develop a downstream partner. Or perhaps the NxStage machine is deficient in some way. As a result, perhaps NxStage was dead in the water. ${ }^{69}$ If so, this would be a key fact, so it would have been useful for the Commissioners to explain why NxStage's future prospects as an independent competitor also were dim.

Discussion of future equipment market competition concerns did arise in the analysis of customer foreclosure. Commissioner Chopra expressed the concern that Fresenius would only use NxStage machines after the merger, which then would raise barriers to entry to future

\footnotetext{
${ }^{68}$ This was suggested by Commissioner Chopra. See Fresenius Chopra Statement, supra note 7, at 4 ${ }^{69}$ If this were the case, it may be at least partially the result of the agencies permitting this industry to consolidate by clearing the history of acquisitions.
} 
entrants by making it harder for them to achieve minimum viable scale, which then would delay or inhibit entry. ${ }^{70}$ However, one caution here is that a finding that an independent NxStage would have been achieved a substantial market share absent the merger similarly would have a deterring effect on future new entrants, though perhaps not to the same extent as Fresenius' ownership of NxStage. The majority rejected this customer foreclosure concern for a different reason, the existence of potential entrants who may not have complained. ${ }^{71}$ In any event, this customer foreclosure impact on future potential entrants may be secondary to the possible effects of the merger in eliminating the actual potential competition in the equipment market by NxStage.

The majority statement analyzes input foreclosure, which is somewhat related to the killer acquisition theory. ${ }^{72}$ Input foreclosure can be illustrated with Figure 7, where the "bubble" for fringe machine suppliers is deleted to unclutter the picture. Input foreclosure would involve a post-merger Fresenius having the incentive to withhold or raise the price of the NxStage machine from its existing competitors such as DaVita as well as downstream potential entrants. ${ }^{73}$ The majority statement concludes that the evidence showed that input foreclosure is unlikely. ${ }^{74}$ Commissioner Slaughter disagreed. She concluded that "the investigation indicated that these strategies could be profitable for Fresenius." 75 No further discussion of the source of these dueling conclusions is provided, however.

Entry upstream in principle can deter input foreclosure. CVS apparently announced during the period of the investigation that it was developing an in-home machine. To this point, CVS might become viable because it could enter at both levels. This raises the question of

\footnotetext{
${ }^{70}$ Fresenius Chopra Statement, supra note 7, at 3.

${ }^{71}$ Fresenius Majority Statement, supra note 7, at 2.

${ }^{72}$ Fresenius Majority Statement, supra note 7, at 1 . This is related to the killer acquisition theory because the recoupment could involve elimination in diversion to in-home services by NxStage downstream partners.

${ }^{73}$ If Fresenius were truly a monopolist protected by barriers to entry and NxStage were permanently dead in the water, then foreclosure might be unnecessary for Fresenius to achieve monopoly profits. But, this theory depends on that assumption about NxStage also would represent no likely future competitive constraint.

${ }^{74} I d$.

${ }^{75}$ Fresenius Slaughter Statement, supra note 7, at 2.
} 
whether the equipment of CVS (or other potential entrants) would be as innovative as the NxStage machine. ${ }^{76}$ This also raises the issue of the timing and likelihood of entry. The CVS machine apparently will still need to gain FDA approval. Commissioner Slaughter raised the concern that there were significant barriers to entry. ${ }^{77}$ In this regard, the majority statement does not discuss whether the entry by CVS or others would be timely, likely and sufficient in light of the FDA regulations and other potential impediments to entry.

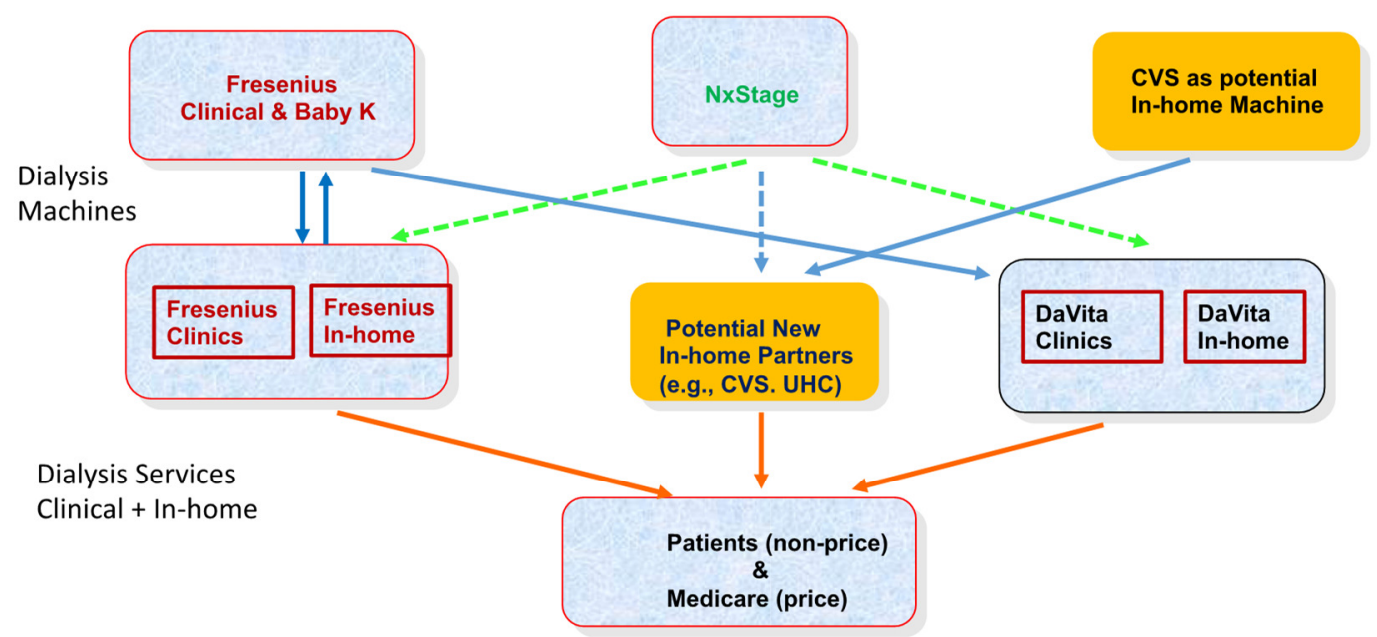

Figure 7: Dialysis Market Structure (Including NxStage \& CVS)

The majority reports that " $[\mathrm{t}]$ he totality of the evidence also shows that Fresenius has a strong record of supplying other clinics with hemodialysis products." presumably charges high prices, so that additional competition in the equipment market from NxStage (and CVS) likely would be beneficial. This history of supplying competitors also does not address Fresenius' possible incentive to protect its clinic business from in-home competition.

The disagreement among the Commissioners could stem from the majority demanding a higher evidentiary burden on the demonstration of competitive harm. In principle,

\footnotetext{
${ }^{76}$ In addition, if CVS were going to enter even absent the merger, then the merger would have reduced the number of equipment competitors, ceteris paribus.

${ }^{77}$ Fresenius Slaughter Statement, supra note 7, at 1.

${ }^{78}$ Fresenius Majority Statement, supra note 7, at 1.
} 
this higher burden could flow either from their analysis of the potential efficiencies of the transaction or from their presuming such efficiencies. According to the majority, the acquisition will create efficiency benefits by increasing Fresenius' incentives to expand into in-home sales by aligning incentives, which could include elimination of double marginalization. ${ }^{79}$ At the same time the majority says that "we do not rest our decision on the presence of efficiencies." 80 Thus, it appears that the majority was relying on an efficiency presumption, not evidence.

Commissioner Chopra concluded that the efficiencies were not merger-specific because they could be achieved by contract absent the merger. ${ }^{81}$ The majority disagreed, saying that "present-day realities show that the parties have not achieved the same result via contract." 82 However, this historical fact assumes rather than proves merger-specificity. Proof would involve a showing that the parties tried and failed to successfully negotiate a more efficient contract, or a showing why such negotiation clearly would have been futile. After all, it would not make sense for the Commission to permit an otherwise anticompetitive merger, if the failure to achieve efficiency by contract was simply a lack of effort, or recalcitrance designed to justify a future merger. ${ }^{83}$

As in the case of Jeld-Wen/CMI, it may have been the case that there were no complaints about this merger. But, if Fresenius gaining control of NxStage would facilitate coordination with DaVita by preventing competition by independent in-home service providers, DaVita might not have an incentive to complain, as discussed above. The more likely complainers would be the potential outpatient service providers. But, substantial outpatient service providers apparently did not yet exist. If CVS already were developing its own machine, then it might

${ }^{79} I d$. at 1.

${ }^{80} I d$. at 2 . The majority statement also says that the merger "potentially would increase the use of inhome machines dramatically - that is, profit by expanding the business it proposes to purchase, supporting NxStage's superior in-home machines with Fresenius' superior scale and service." Id. (emphasis added).

${ }^{81}$ Fresenius Chopra Statement, supra note 7, at 4.

${ }^{82}$ Fresenius Majority Statement, supra note 7, at 2.

${ }^{83}$ For example, in a horizontal merger, it seems doubtful that parties could justify an otherwise anticompetitive merger on the grounds that the merger would allow the parties to end a patent infringement case or eliminate a patent royalty. For further discussion, see Baker et. al., supra note 8 at $13-15$. 
have welcomed Fresenius' acquisition as a way to eliminate competition against its own in-home machine and so would not have the incentive to complain. Again, these are questions that one hopes were answered during the staff investigation.

In the end, this may well be a case where (i) (legal) tacit coordination between Fresenius and DaVita to forgo competition by purchasing and promoting NxStage machines, (ii) the absence of alternative service providers, and (iii) NxStage's inability to enter at both levels in combination prevented NxStage from succeeding in the non-merger world and would continue to do so into the future. It also may be that there were no alternative acquirers of NxStage that could have overcome these impediments. It is also possible that the NxStage machine had quality problems. If these were the facts, then there would be no false negative.

Finally, this case raises another interesting enforcement issue. Taking a longer-term view, it could be the case that that the failure of NxStage to succeed may have been the unintended result of previous merger enforcement that led to dominance of the clinical dialysis services market by two firms. There were numerous such acquisitions including the following. In 2005, the Commission approved a large clinic acquisition by DaVita of Gambro, which made DaVita the largest U.S. clinical provider at the time. ${ }^{84}$ In 2006, Fresenius acquired the clinics of. Renal Care Group, which then was the third-largest clinical provider. ${ }^{85}$ In 2011, the Commission approved DaVita's acquisition of DSI, which then was the fifth-largest dialysis chain. ${ }^{86}$ In 2012 ,

\footnotetext{
${ }^{84}$ Before the merger, DaVita had 655 U.S. clinics and Gambro had 565. The FTC required divestiture of 69 clinics and two management contracts. See Press Release, Fed. Trade Comm'n, FTC Accepts Settlement to Remedy DaVita's Acquisition of Rival Outpatient Dialysis Clinic Provider Gambro (Oct. 4, 2005), https://www.ftc.gov/news-events/press-releases/2005/10/ftc-accepts-settlement-remedy-davitasacquisition-rival.

${ }^{85}$ Renal Care Group owned 450 clinics. At the time, Fresenius had 1155 clinics. The FTC required divestiture of 91 clinics and financial interests in 12 more. See Press Release, Fed. Trade Comm'n, Maintaining Competition, FTC Allows Fresenius \$3.5 Billion Deal to Buy Rival Dialysis Provider Renal Care Group (Mar. 31, 2006), https://www.ftc.gov/news-events/press-releases/2006/03/maintainingcompetition-ftc-allows-fresenius-35-billion-deal-buy.

${ }^{86}$ DSI owned 106 dialysis centers. At the time, DaVita had 1612 clinics. The FTC required divestiture of 29 clinics. Press Release, Fed. Trade Comm'n, FTC Requires Dialysis Services Company DaVita, Inc. to Sell 29 Clinics to Resolve Anticompetitive Effects of its Proposed Acquisition of DSI (Sept. 2, 2011), https://www.ftc.gov/news-events/press-releases/2011/09/ftc-requires-dialysis-services-company-davitainc-sell-29.
} 
Fresenius acquired the clinics of Liberty Dialysis Holding, which then was the third-largest dialysis chain. ${ }^{87}$

In these matters, the Commission analyzed competition in local geographic markets for clinic hemodialysis services. However, while the downstream markets are local, the upstream market for the purchase or sale of dialysis equipment would be national. ${ }^{88}$ By allowing Fresenius and DaVita to achieve an effective duopoly in the downstream market, the policy also endowed these firms with buy-side market power in the upstream equipment market. It is this buy-side market power that may have prevented NxStage from becoming more successful. Thus, clearing these earlier acquisitions could have led to subsequent entry barriers that prevented the equipment market from self-correcting and the services market from becoming more competitive. That is not to say that the decision in this case was a false negative, rather the previous permissive merger enforcement arguably were false negatives.

\section{Conclusions and Policy Implications}

The lack of detailed analysis in the Commissioners' statements makes it difficult to completely understand or evaluate the Commission staff analysis, as I have emphasized. It is disappointing that the Commissioners often simply stated that they disagreed with one another on some of these key issues, rather than rebutting each other's arguments in detail with the relevant facts. Transparency would be greatly enhanced if they would have revealed further details of their analysis and the specifics of their factual disagreements. Simply stating one's position without explaining the underlying source of the factual disagreement or criticism of the opposing position leaves outsiders with a cloudy view.

Gaining greater understanding is important. The business community and their advisors need to understand the Commission's approach to vertical mergers in order to decide whether to propose vertical acquisitions. At this time, the tea leaves simply seem to indicate more 3-2 votes

\footnotetext{
${ }^{87}$ Liberty owned 260 U.S. clinics. At the time, Fresenius had 1800 clinics. The FTC required divestiture of 60 clinics and one management contract. See Press Release, Fed. Trade Comm'n, FTC Requires Fresenius Medical Care AG to Sell 60 Dialysis Clinics Around the Country as a Condition of Acquiring Liberty Dialysis Holdings, Inc. (Feb. 28, 2012), https://www.ftc.gov/news-events/pressreleases/2012/02/ftc-requires-fresenius-medical-care-ag-sell-60-dialysis-clinics.

${ }^{88} \mathrm{~A}$ worldwide market is possible, though FDA regulatory requirements might have limited the market to the U.S.
} 
at the FTC. Careful evaluation of the staff analysis also is necessary to advance and improve merger analysis going forward. This is particularly important in light of the limited number of merger retrospectives that can be undertaken.

For these reasons, I agree with Commissioner Chopra that would be useful for the Commission to release more detailed analyses of these and future mergers as a way to increase transparency. ${ }^{89}$ Release of further factual analysis would require redaction of confidential information, of course. However, even with redactions, antitrust counselors and merging companies would gain a better understanding the type of analysis that the Commission finds relevant and credible in vertical merger matters.

DOJ's false negative decision Jeld-Wen/CMI merger that was revealed by the postmerger conduct and successful private litigation should be an object lesson for the need for careful investigation of the full range of possible competitive concerns, including the Frankenstein Monster scenario. If it were the case that the Frankenstein Monster scenario was ignored in Staples/Essendant, and if there were insufficient cognizable efficiencies, that decision also might have been a false negative. ${ }^{90}$

DOJ's false negative also indicates the need for the enforcement agencies to monitor post-merger conduct in a non-defensive, objective manner. It also indicates the need for the agencies to remain prepared to bring enforcement actions if the mergers subsequently turn out to have anticompetitive effects. To facilitate those actions, it would be beneficial to build performance standards into consent decrees to give the agencies the ability to modify consent decrees if it becomes necessary to do so. ${ }^{91}$

The Commissioners agreed that retrospectives were a good idea. However, a concern was raised about resource scarcity, which would constrain the ability to carry out numerous merger retrospectives. A good solution to this problem would be to have the retrospectives carried out by objective academic researchers acting as agency consultants. These studies would be subject to appropriate confidentiality restrictions on disclosing the data. Public reports would be subject to the usual redactions of confidential information. This approach would reduce the

\footnotetext{
${ }^{89}$ Fresenius Chopra Statement, supra note 7, at 4.

${ }^{90}$ Efficiencies are cognizable if they are verifiable, merger-specific and sufficient to reverse the anticompetitive concerns. MERGER GUIDELINES, supra note 42, at 30.

${ }^{91}$ For details, see Salop, supra note 57.
} 
cost. The independence of the researchers also would help to achieve objectivity. ${ }^{92}$ As noted earlier, agency staff might be prone to unconscious confirmation bias, particularly if they previously worked on the merger during the HSR investigation or feel a general need to defend their agency.

The resource scarcity of the FTC and DOJ is significant and goes beyond the issue of merger retrospectives. Figure 8 plots the relationships between the combined annual budgets of the (entire) FTC and DOJ Antitrust Division since 2009 relative to the value of U.S. mergers and acquisitions. ${ }^{93}$ Since 2009 , the agencies budgets have fallen by about $70 \%$, relative to the value of the merger transactions. Larger mergers require more analysis, but budgets have not kept pace. Moreover, even this comparison understates the resource constraint. The growing economic complexity and greater quantification of possible effects in the typical merger analysis means that more analysis and resources are needed for each transaction.

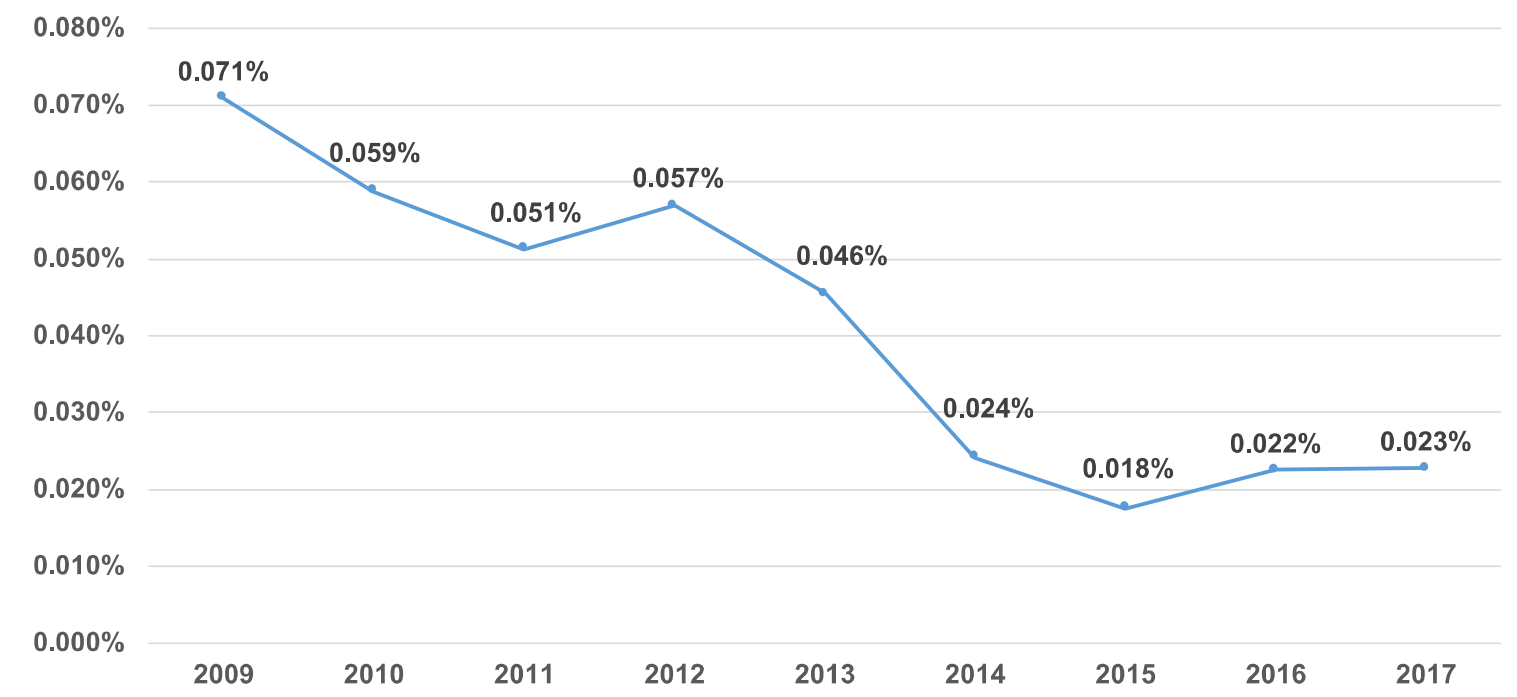

Figure 8: Ratio of Agency Budgets (FTC + ATR) to M\&A Value

\footnotetext{
${ }^{92}$ If the researchers have economic and policy presumptions, it might be useful to have multiple studies.

${ }^{93}$ Figure 8 combines the data from the following sources: FED. TRADE COMM'N, FTC APPROPRIATION AND FULL-TIME EQUIVALENT HISTORY, https://www.ftc.gov/about-ftc/bureaus-offices/office-executivedirector/financial-management-office/ftc-appropriation (last visited Mar. 9, 2019); DEP'T OF JUSTICE, APPROPRIATION FIGURES FOR THE ANTITRUST DIVISION FISCAL YEARS 1903-2019, https://www.justice.gov/atr/appropriation-figures-antitrust-division (last visited Mar. 9, 2019); M\&A data from Bloomberg Finance L.P.
} 
When resources are limited, the agencies necessarily must engage in investigation and enforcement triage, which will unavoidably lead to more anticompetitive transactions slipping through or weaker consents, despite the best efforts of the agencies. This suggests the need for Congress to allocate higher budgets to the enforcement agencies. An alternative would be for the courts to reduce the agency's required burden of proof in merger cases. This policy would allow the agencies to maintain adequate enforcement and avoid increased false negatives that would conflict with the implementation of the incipiency standard in Section 7 law. The agencies also might interpret the incipiency standard accordingly.

In fact, this issue goes beyond these budget constraints. As antitrust analysis has become more complex and substantial quantification has become the norm, the litigation advantage has tipped significantly in favor of the merging firms. Since the plaintiff has the burden of persuasion, complexity favors defendants on balance. This plaintiff disadvantage is larger in that generalist judges might understand the existence of technical criticisms of plaintiff's quantitative evidence, but find it more difficult to evaluate the relative importance of these criticisms in weakening the conclusions that can be drawn from the plaintiff's evidence.

Finally, the Fresenius/NxStage merger also provides an interesting connection of how permissible acquisitions in downstream output markets can lead to buy-side market power problems in national input markets. In the case of hemodialysis, it is possible that high concentration across the local geographic markets for dialysis services led to buy-side market power by Fresenius and DaVita that prevented NxStage from being able to grow the in-home market. The failure to consider such upstream effects is not new. A similar issue arose in the pay-TV industry, where consolidation in local subscriber markets created market power in the sale of national access to online video distributors and ultimately led to the DOJ concerns and subsequent abandonment of the proposed Comcast/Time Warner Cable merger in $2015 .{ }^{94}$ Now that antitrust analysis of monopsony and buyer-side issues has become more prominent, the agencies likely will pay more attention to the upstream impact of horizontal mergers in addition to any competitive concerns in local downstream markets.

\footnotetext{
${ }^{94}$ Press Release, Dep't of Justice, Comcast Corporation Abandons Proposed Acquisition of Time Warner Cable After Justice Department and the Federal Communications Commission Informed Parties of Concerns (Apr. 24, 2015), https://www.justice.gov/opa/pr/comcast-corporation-abandons-proposedacquisition-time-warner-cable-after-justice-department.
} 
